Collection: Cost Action E29 Meeting 2008 - Istanbul (Turkey)

Future Monitoring and Research Needs for Forest Ecosystems

Guest Editor: Marcus Schaub (WSL, Birmensdorf, $\mathrm{CH}$ )

\section{Dynamic modelling of target loads of acidifying deposition for forest ecosystems in Flanders (Belgium)}

\begin{abstract}
Staelens $\mathrm{J}^{(1-2)}$, Neirynck $\mathrm{J}^{(2)}$, Genouw $\mathrm{G}^{(2)}$, Roskams $\mathbf{P}^{(2)}$
The aim of this study was to determine target loads for acidification for representative forest ecosystems in Flanders (Belgium) using dynamic modelling. Target loads were calculated for $\mathbf{8 3}$ forest stands for which sufficient measurements were available. This dataset is considered to be representative for the Flemish forest area. It is concluded that, despite the inherent uncertainty in modelling soil acidification at a regional level, important $\mathrm{N}$ and $\mathrm{S}$ deposition reductions are needed to allow recovery of the Flemish forest soils.
\end{abstract}

Keywords: Acidifying deposition, Critical load, Ecosystem recovery, VSD model, Target load

\section{Introduction}

The input of nitrogen $(\mathrm{N})$ and sulphur $(\mathrm{S})$ to terrestrial and aquatic ecosystems has strongly increased over the past century due to human activities. This particularly holds true for forest ecosystems in Europe (de Vries et al. 2003) and NE America (Lovett \& Lindberg 1993). Chronically enhanced $N$ and $\mathrm{S}$ deposition results in varying ecosystem responses, including increased biomass growth, but also soil acidification, changes in plant species composition and nutrient availability, increased $\mathrm{N}$ emission losses, and increased nitrate, sulphate, and cation losses by leaching below the rooting zone (Aber et al. 1998, van Dobben et al. 2006).

For forest and nature policy it is important to know the highest deposition level below which no harmful effects on forest soils occur. Therefore, the concept of critical loads

(1) Laboratory of Forestry, Laboratory of Applied Physical Chemistry, Ghent

University, Coupure links 653, 9000 Gent, Belgium; (2) Research Institute for Nature and Forest, Gaverstraat 4, 9500

Geraardsbergen, Belgium

(a), Jeroen Staelens

(Jeroen.Staelens@UGent.be)

Received: Mar 13, 2008 - Accepted: Dec 09, 2008

Citation: Staelens J, Neirynck J, Genouw G, Roskams P, 2009. Dynamic modelling of target loads of acidifying deposition for forest ecosystems in Flanders (Belgium). iForest 2: 30-33 [online: 2009-01-21] URL: http://www.sisef.it/iforest/show.php? id $=484$ has been adopted, i.e., the highest deposition of acidifying compounds that will not cause chemical changes leading to long-term harmful effects on ecosystem structure and function according to present knowledge (UBA 2004). Critical loads are determined using a static mass balance in which the ecosystem is assumed to be in equilibrium with the deposition. However, many forest ecosystems are not in steady-state due to processes such as cation exchange, sulphate desorption and $\mathrm{N}$ immobilisation, which create time lags between changes in deposition and chemical soil status (e.g., Neirynck et al. 2002). Consequently, dynamic models that account for these buffering processes are required to simulate the effect of changing atmospheric inputs on forest soils through time. This allows to determine a target load, i.e., the deposition for which a chosen chemical status is respected from a target year on (UBA 2004).

The $\mathrm{N}$ and $\mathrm{S}$ deposition in Flanders (northern Belgium) is amongst the highest in Europe (UNECE 2003). While critical loads have been calculated for the acidifying and eutrophying effects of $\mathrm{N}$ and $\mathrm{S}$ deposition onto various ecosystems, soil buffering mechanisms have not yet been taken into account. Therefore, the aim of this study was to determine target loads for acidification for representative forest ecosystems in Flanders using dynamic modelling.

\section{Summary of methods}

Critical loads and target loads were calculated for 83 forest stands of the Flemish forest condition (Level I) and intensive mon- itoring (Level II) networks according to the harmonized methodology of the Coordination Center of Effects (UBA 2004). The Very Simple Dynamic (VSD) model was used for simulating the chemical composition of soil and soil solution throughout time (1880-2100) based on soil characteristics and rainfall, deposition and growth data. The VSD model is largely based on the soil model SMART (de Vries et al. 1989, Posch et al. 1993) that has been simplified by: (i) neglecting calcareous soils and aluminium depletion in highly acidified soils; (ii) ignoring sulphate adsorption; (iii) assuming complete nitrification, thus ignoring $\mathrm{NH}_{4}{ }^{+}$leaching; and (iv) lumping the exchange of all base cations in one term. Furthermore, it uses a new approach of modelling $\mathrm{N}$ immobilisation. More information on VSD is given in Reinds et al. (2008). In the present study, the mass balance of $\mathrm{N}$ included atmospheric deposition, soil immobilisation, growth uptake, denitrification, and soil leaching. The exact VSD equations used are given in UBA (2004). The year 2010 was used as the starting year of deposition reductions, with 2020 the implementation year of a target load. Target loads were calculated that resulted in a maximum aluminium to base cation ratio (molar $\mathrm{Al}: \mathrm{Bc}=1)$ in the soil solution from three target years on $(2030,2050$, and 2100). Input data were as much as possible derived from site-specific measurements or regional data, following guidelines of UBA (2004) and described in detail by Staelens et al. (2006). Soil parameters included (i) mineral weathering of base cations $\left(\mathrm{K}^{+}, \mathrm{Ca}^{2+}\right.$, and $\mathrm{Mg}^{2+}$ ), estimated from the measured soil type, (ii) cation exchange, derived from the measured cation exchange capacity and the Gapon exchange model, with exchange coefficients calibrated by the VSD model, (iii) denitrification, estimated from soil drainage status and assuming total nitrification, and (iv) nitrogen immobilisation, modelled based on the measured carbon to nitrogen $(\mathrm{C}: \mathrm{N})$ ratio of the litter and upper $0-20 \mathrm{~cm}$ soil layers. Time series of atmospheric $\mathrm{N}$ and $\mathrm{S}$ deposition were provided by EMEP (Convention on Long-range Transboundary Air Pollution, CLRTAP). Base cation and chloride deposition were assumed to be constant over time and were derived from throughfall data corrected for ion exchange within the canopy. The growth uptake of nitrogen and base cations was calculated using tree speciesspecific annual wood production and nutrient contents. The annual percolation flux below the rooting zone was quantified by combining regionally interpolated rainfall with species-specific rainfall interception and actual evapotranspiration values. Model sensitivity was assessed for all stands by varying the input data and model parameters within rea- 
(A)



(B)

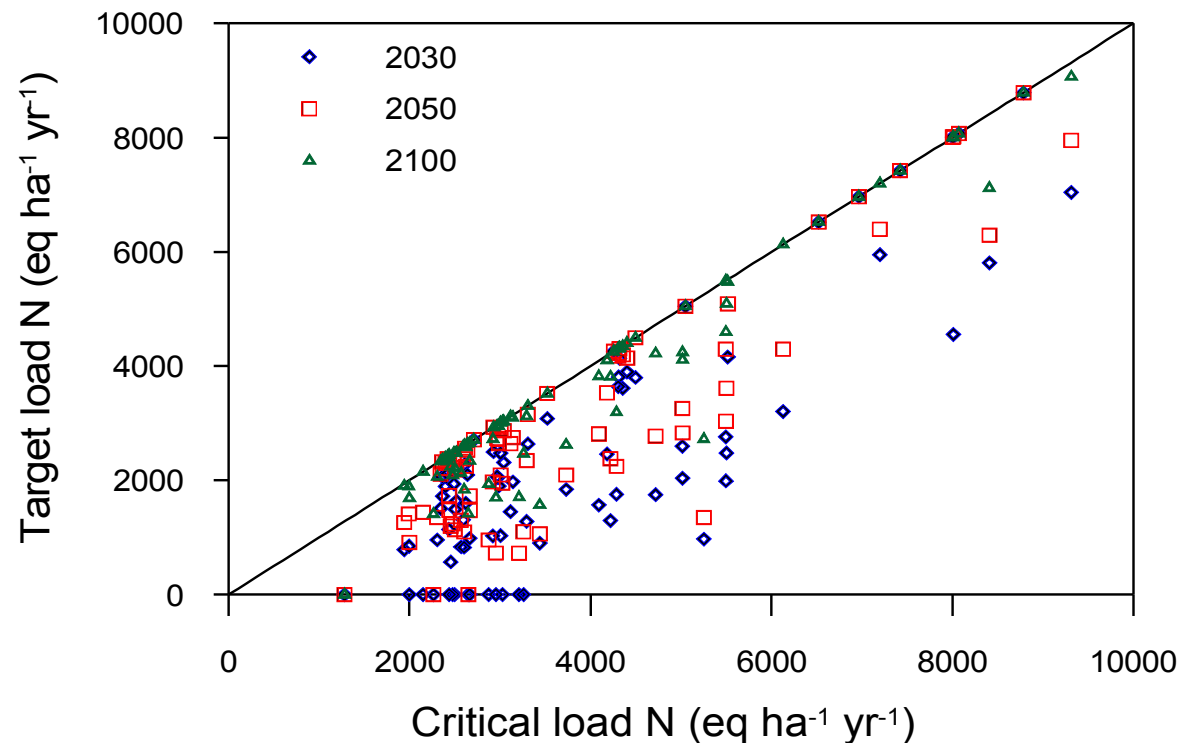

Fig. 1 - Relationship between target loads for 2030, 2050, and 2100 and critical loads for (A) sulphur, S, and (B) acidifying nitrogen, N, for 83 Flemish forest sites. Note: the diagonal indicates a 1:1 ratio.

Tab. $1-5^{\text {th }}, 50^{\text {th }}$ (median), and $95^{\text {th }}$ percentile values of the target load for three target years and critical load (eq $\mathrm{ha}^{-1} \mathrm{yr}^{-1}$ ) for sulphur (S) and acidifying nitrogen (N) for 83 Flemish forest sites.

\begin{tabular}{lcccccc}
\hline \multirow{2}{*}{ Loads } & \multicolumn{3}{c}{$\mathbf{S}\left(\mathbf{e q ~ h a}^{-\mathbf{1}} \mathbf{y r}^{-1}\right)$} & \multicolumn{3}{c}{$\mathbf{N}\left(\mathbf{e q ~ h a}^{-\mathbf{1}} \mathbf{y r}^{-\mathbf{1}}\right)$} \\
\cline { 2 - 7 } & $\mathbf{5 \%}$ & $\mathbf{5 0 \%}$ & $\mathbf{9 5 \%}$ & $\mathbf{5 \%}$ & $\mathbf{5 0 \%}$ & $\mathbf{9 5 \%}$ \\
\hline Target load 2030 & 0 & 811 & 2464 & 0 & 1938 & 7947 \\
Target load 2050 & 41 & 1324 & 2873 & 747 & 2564 & 8011 \\
Target load 2100 & 478 & 1598 & 2885 & 1691 & 2958 & 8064 \\
Critical load & 919 & 1829 & 2885 & 2162 & 3115 & 8374 \\
\hline
\end{tabular}

sonable ranges.

Critical loads and target loads of acidifying deposition indicate a sum of $\mathrm{N}$ and $\mathrm{S}$ deposition that allow the soil and soil solution to reach a chemical criterion in the long term or in the target year, respectively. If only $\mathrm{S}$ contributes to soil acidification, the acceptable $\mathrm{S}$ deposition is called the maximum critical or target load of S. If the S deposition is zero, the acceptable $\mathrm{N}$ deposition is the maximum critical or target load of acidifying N (UBA 2004).

\section{Results and discussion}

Target loads depend on the target year by which the preset chemical criterion $(\mathrm{Al}: \mathrm{Bc}=$ 1) in the soil solution should be achieved at last. Target loads are higher for more future target years (Fig. 1) as this corresponds to allowing a longer time period with lowered $\mathrm{N}$ and $\mathrm{S}$ deposition during which soils can recover from acidification. To respect the $\mathrm{Al}: \mathrm{Bc}$ criterion from target year 2050 on, stronger reductions in $\mathrm{N}$ and $\mathrm{S}$ deposition than in the Gothenburg agreements (CLRTAP) were needed in $84 \%$ of the plots. In $12 \%$ of the plots no additional deposition reductions were needed, while for $4 \%$ the criterion could not be reached. For target year 2030, the criterion was not feasible for $17 \%$ of the plots.

The median $(\mathrm{n}=83)$ target load of $\mathrm{S}$ for 2030, 2050, and 2100 amounted to 58, 65, and $86 \%$ of the median critical load of S (being $1829 \mathrm{eq} \mathrm{ha}^{-1} \mathrm{yr}^{-1}$ ), respectively (Tab. 1). The target loads of $\mathrm{N}$ differed less from the critical load of $\mathrm{N}$ than for $\mathrm{S}$ due to the timedependent soil $\mathrm{N}$ immobilisation. Target and critical loads of $\mathrm{N}$ were always higher than for $\mathrm{S}$ because of this $\mathrm{N}$ immobilisation, $\mathrm{N}$ growth uptake and denitrification. However, enhanced $\mathrm{N}$ inputs not only affect terrestrial ecosystems through soil acidification (cf. Introduction). To avoid changes in species composition or nitrate leaching to the groundwater, other critical loads are used (UBA 2004) that result in lower acceptable $\mathrm{N}$ loads than in the present study (Staelens et al. 2006), in which we calculated the acceptable acidifying $\mathrm{N}$ deposition.

The critical and target loads were lower for deciduous than for coniferous stands (Fig. 2) because of the higher base cation uptake by deciduous trees. As an example, for sandy soils the median target load of $\mathrm{S}$ for 2050 was $275 \mathrm{eq} \mathrm{ha}^{-1} \mathrm{yr}^{-1}$ for deciduous stands $(\mathrm{n}=$ 25) and $1638 \mathrm{eq} \mathrm{ha}^{-1} \mathrm{yr}^{-1}$ for coniferous stands $(\mathrm{n}=27)$. The acceptable acidifying deposition was lowest for forests on sandy soils because of the lower mineral weathering rates compared to loamy or clayey soils (Fig. 2 - van der Salm \& de Vries 2000).

According to the sensitivity analysis (Tab. 2 ), the calculated target loads for 2050 depended mostly on the base cation fluxes by mineral weathering, deposition, and net 
(A)

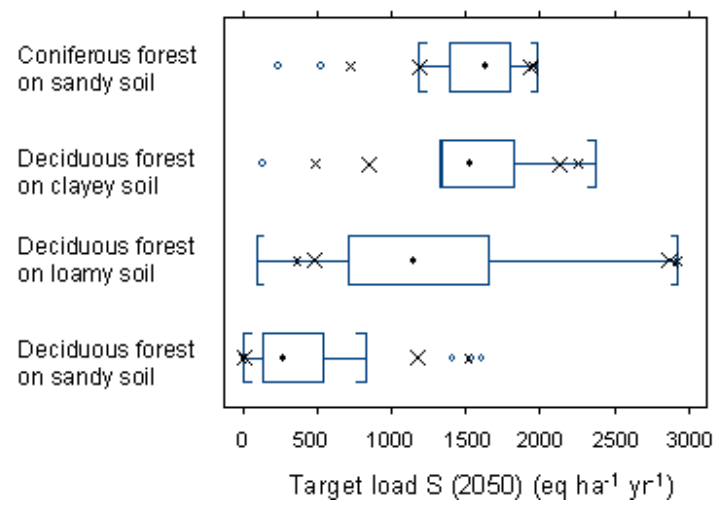

(B)

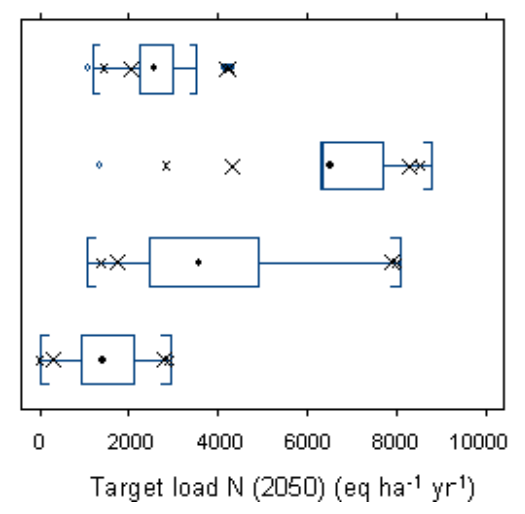

Fig. 2 - Boxplots $(n=83)$ of target loads for (A) sulphur, S, and (B) acidifying nitrogen, N, for target year 2050 for the main combinations of forest type and soil type in Flanders. Note: The closed rectangle of the boxplots indicates the interquartile range $(25-75 \%)$ of the distribution, the dot being the median. The small $\mathrm{x}$ and large $\mathrm{X}$ left (right) of the rectangle show the $5^{\text {th }}\left(95^{\text {th }}\right)$ and $10^{\text {th }}$ $\left(90^{\text {th }}\right)$ percentiles, respectively. The [ ] range comprises all values closer to the median than 1.5 times the interquartile range. Values outside the [ ] range are shown individually as open circles.

Tab. 2 - Median $(n=83)$ target load (TL, target year 2050) and critical load (CL) for sulphur (S) and acidifying nitrogen (N) using modified input parameters and variables. All values are expressed as the difference (\%) compared to the reference approach values $\left(\mathrm{eq} \mathrm{ha}^{-1} \mathrm{yr}^{-1}\right)$. $(-)$ : Parameter not used for calculating critical loads.

\begin{tabular}{|c|c|c|c|c|c|}
\hline \multirow{2}{*}{ Input parameter } & \multirow{2}{*}{ Modification } & \multicolumn{2}{|c|}{ Median TL 2050} & \multicolumn{2}{|c|}{ Median CL } \\
\hline & & $\mathbf{S}$ & $\mathbf{N}$ & $\mathbf{S}$ & $\mathbf{N}$ \\
\hline Reference approach & & 1324 & 2564 & 1829 & 3115 \\
\hline \multirow[t]{2}{*}{ Mineral weathering rate $\left(\mathrm{BC}_{\mathrm{w}}\right)$} & $\mathrm{BC}_{\mathrm{w}}+20 \%$ & 14.5 & 9.4 & 3.2 & 3.3 \\
\hline & $\mathrm{BC}_{\mathrm{w}} \ddot{\boldsymbol{i}} 20 \%$ & -21.7 & -10.5 & -12.9 & -4.9 \\
\hline \multirow[t]{2}{*}{ Denitrification factor $\left(f_{d e}\right)$} & $\mathrm{f}_{\mathrm{de}}+20 \%$ & 2.7 & 9.4 & 0.0 & 14.9 \\
\hline & $\mathrm{f}_{\mathrm{de}} \ddot{\boldsymbol{i}} 20 \%$ & -3.1 & -7.6 & 0.0 & -9.3 \\
\hline Minimal denitrification & $\mathrm{f}_{\mathrm{de}}=0.1$ & -13.2 & -15.0 & 0.0 & -19.6 \\
\hline \multirow[t]{2}{*}{ Acceptable $\mathrm{N}$ immobilisation $\left(\mathrm{N}_{\mathrm{i}, \mathrm{acc}}\right)$} & $\mathrm{N}_{\mathrm{i}, \mathrm{acc}}+20 \%$ & 0.4 & 2.4 & 0.0 & 1.9 \\
\hline & $\mathrm{N}_{\mathrm{i}, \mathrm{acc}} \ddot{\boldsymbol{Z}} 20 \%$ & 0.0 & -2.0 & 0.0 & -1.9 \\
\hline Minimal N immobilisation & $\mathrm{N}_{\mathrm{i}, \mathrm{acc}}=1 \mathrm{~kg} \mathrm{ha}^{-1} \mathrm{yr}^{-1}$ & -0.9 & -8.2 & 0.0 & -5.2 \\
\hline \multirow{2}{*}{ Deposition of base cations $\left(\mathrm{Bc}_{\mathrm{dep}}\right)$} & $\mathrm{Bc}_{\mathrm{dep}}+20 \%$ & 48.5 & 38.5 & 23.6 & 25.7 \\
\hline & $\mathrm{Bc}_{\mathrm{dep}} \ddot{\boldsymbol{l}} 20 \%$ & -56.2 & -33.4 & -24.6 & -24.3 \\
\hline \multirow{6}{*}{$\begin{array}{l}\text { Growth uptake of nitrogen }\left(\mathrm{N}_{\mathrm{u}}\right) \\
\text { and base cations }\left(\mathrm{Bc}_{\mathrm{u}}\right)\end{array}$} & $\mathrm{N}_{\mathrm{u}}$ and $\mathrm{Bc}_{\mathrm{u}}+20 \%$ & -22.4 & -10.4 & -14.1 & -7.2 \\
\hline & $\mathrm{N}_{\mathrm{u}}$ and $\mathrm{Bc}_{\mathrm{u}}-20 \%$ & 17.1 & 12.0 & 5.3 & 9.2 \\
\hline & $\mathrm{Bc}_{\mathrm{u}}+20 \%$ & -23.2 & -14.8 & -14.1 & -9.2 \\
\hline & $\mathrm{Bc}_{\mathrm{u}} \ddot{\boldsymbol{i}} 20 \%$ & 20.7 & 17.6 & 5.3 & 11.3 \\
\hline & $\mathrm{N}_{\mathrm{u}}+20 \%$ & 1.3 & 4.8 & 0.0 & 3.3 \\
\hline & $\mathrm{N}_{\mathrm{u}} \ddot{\boldsymbol{l}} 20 \%$ & -1.3 & -7.3 & 0.0 & -3.3 \\
\hline \multirow[t]{2}{*}{ Drainage flux (Q) } & $Q+20 \%$ & -1.8 & -0.3 & -0.3 & -0.5 \\
\hline & $\mathrm{Q} \ddot{\boldsymbol{i}} 20 \%$ & 1.3 & -0.2 & 0.2 & 0.4 \\
\hline \multirow{2}{*}{$\begin{array}{l}\text { Parameters for } \mathrm{Al}^{3+}-\mathrm{H}^{+} \text {concentration } \\
\text { relationship }\left(\log \mathrm{K}_{\text {Alox }}, \text { expAl) }\right.\end{array}$} & $\log \mathrm{K}_{\text {Alox }}+0.5$ & -9.0 & -5.1 & -4.6 & -4.2 \\
\hline & $\log \mathrm{K}_{\text {Alox }} \ddot{\boldsymbol{i}} 0.5$ & 10.6 & 5.4 & 5.9 & 5.8 \\
\hline Dutch empirical values & (UBA 2004) & -11.9 & 10.4 & 13.0 & 23.0 \\
\hline Dissociation of organic anions & $\mathrm{m} \cdot \mathrm{DOC}+20 \%$ & -4.9 & -1.1 & -1.7 & -1.7 \\
\hline \multirow{2}{*}{ Concentration $(\mathrm{m} \cdot \mathrm{DOC})$} & mDOC $\ddot{\imath} 20 \%$ & 4.5 & 1.1 & 1.6 & 1.7 \\
\hline & $\mathrm{mDOC}=0$ & 14.1 & 11.7 & 7.4 & 8.5 \\
\hline Fixed dissociation constant $\left(\mathrm{pK}_{1}\right)$ & $\mathrm{pK}_{1}=4.5$ & 7.7 & 2.7 & 3.7 & 3.8 \\
\hline \multirow[t]{2}{*}{ Factor partial $\mathrm{CO}_{2}$ pressure $\left(\mathrm{pCO}_{2}\right)$} & $\mathrm{pCO}_{2}=25$ & -0.4 & -0.1 & -0.2 & -0.2 \\
\hline & $\mathrm{pCO}_{2}=5$ & 0.9 & 0.1 & 0.2 & 0.2 \\
\hline \multirow[t]{2}{*}{ Cation exchange capacity (CEC) } & $\mathrm{CEC}+20 \%$ & -8.3 & -4.3 & - & - \\
\hline & CEC $\ddot{i} 20 \%$ & 5.9 & 5.7 & - & - \\
\hline \multirow[t]{2}{*}{ Base saturation (BS) } & $\mathrm{BS}+20 \%$ & -6.9 & -2.1 & - & - \\
\hline & BS $\ddot{i} 20 \%$ & 3.7 & 6.0 & - & - \\
\hline Cation exchange model & Gaines-Thomas & -31.8 & -25.7 & - & - \\
\hline \multirow[t]{2}{*}{$\mathrm{N}$ deposition $\left(\mathrm{N}_{\mathrm{dep}}\right)$} & $\mathrm{N}_{\mathrm{dep}}+20 \%$ & -2.7 & -3.0 & - & - \\
\hline & $\mathrm{N}_{\mathrm{dep}} \ddot{\boldsymbol{i}} 20 \%$ & 2.9 & 5.2 & - & - \\
\hline \multirow[t]{2}{*}{$\mathrm{S}$ deposition $\left(\mathrm{S}_{\mathrm{dep}}\right)$} & $\mathrm{S}_{\mathrm{dep}}+20 \%$ & -21.1 & -7.5 & - & - \\
\hline & $\mathrm{S}_{\mathrm{dep}} \ddot{\boldsymbol{Z}} 20 \%$ & 11.9 & 7.8 & - & - \\
\hline \multirow[t]{2}{*}{$\mathrm{N}$ and $\mathrm{S}$ deposition } & $\mathrm{N}_{\text {dep }}$ and $\mathrm{S}_{\mathrm{dep}}+20 \%$ & -23.8 & -8.0 & - & - \\
\hline & $\mathrm{N}_{\mathrm{dep}}$ andS $\mathrm{S}_{\mathrm{dep}} \ddot{\boldsymbol{i}} 20 \%$ & 15.9 & 11.5 & - & - \\
\hline
\end{tabular}


growth uptake. Furthermore, the results were clearly affected by the chosen cation exchange model (Gapon vs. Gaines-Thomas) and the assumed relationship between the soil solution $\mathrm{pH}$ and aluminium concentration (cf. van der Salm \& de Vries 2001). For many variables, target loads were more sensitive to changes than critical loads. A $20 \%$ change in the atmospheric deposition of base cations affected the target loads of S more than twice as much as the critical loads. This can be explained by the fact that in the VSD model a constant base cation deposition over the entire simulation period is assumed

Exceedances of target loads were calculated based on projected EMEP depositions for 2010. For target year 2050, the projected depositions were too high for $88 \%$ of the study sites. The median exceedances of acidifying $\mathrm{N}$ and $\mathrm{S}$ deposition for the target years 2030, 2050, and 2100 were 1953, 1443, and $1202 \mathrm{eq} \mathrm{ha}^{-1} \mathrm{yr}^{-1}$.

In the present study, target loads were calculated for 83 forest stands for which sufficient measurements were available. Thanks to the systematic site selection of the forest condition network, this dataset is considered to be representative for the Flemish forest area in general, although coniferous stands were slightly under-represented. This was confirmed by comparing the distribution of critical loads for acidification for the 83 sites with those for a larger database of 1438 plots (Staelens et al. 2006). The range of critical S loads was similar for both datasets, and the median values differed by only $6 \%$. We conclude that, despite the inherent uncertainty in modelling soil acidification at a regional level, important $\mathrm{N}$ and $\mathrm{S}$ deposition reductions are needed to allow recovery of the
Flemish forest soils.

\section{Acknowledgements}

This study was funded by the Flemish Environment Agency (VMM - MIRA) and implemented at the Research Institute for Nature and Forest (INBO). The first author is currently granted as a post-doctoral fellowship at Ghent University by the Research Foundation Flanders (FWO-Vlaanderen).

\section{References}

Aber J, McDowell W, Nadelhoffer K, Magill A, Berntson G, Kamakea M, McNulty S, Currie W, Rustad L, Fernandez I (1998). Nitrogen saturation in temperate forest ecosystems: hypotheses revisited. BioScience 48: 921-934. - doi: 10.2307/1313296

de Vries W, Posch M, Kämäri J (1989). Simulation of the long-term soil response to acid deposition in various buffer ranges. Water, Air and Soil Pollution 48: 349-390.

de Vries W, Reinds GJ, Vel E (2003). Intensive monitoring of forest ecosystems in Europe 2: Atmospheric deposition and its impact on soil solution chemistry. Forest Ecology and Management 174: 97-115. - doi: 10.1016/S03781127(02)00030-0

Lovett GM, Lindberg SE (1993). Atmospheric deposition and canopy interactions of nitrogen in forests. Canadian Journal of Forest Research 23: 1603-1616. - doi: 10.1139/x93-200

Neirynck J, Van Ranst E, Roskams P, Lust N (2002). Impact of decreasing throughfall depositions on soil solution chemistry at coniferous monitoring sites in northern Belgium. Forest Ecology and Management 160: 127-142. - doi: 10.1016/S0378-1127(01)00476-5

Posch M, Reinds GJ, de Vries W (1993). SMART - A simulation model for acidification's regional trends: model description and user manual. Mimeograph Series of the National Board of Waters and the Environment 477, Helsinki, Finland, pp. 43.

Reinds GJ, Van Oijen M, Heuvelink GBM, Kros $\mathrm{H}$ (2008). Bayesian calibration of the VSD soil acidification model using European forest monitoring data. Geoderma 146: 475-488. - doi: 10.1016/j.geoderma.2008.06.022

Staelens J, Neirynck J, Genouw G, Roskams P (2006). Dynamic modelling of target loads for forests in Flanders [in Dutch with English summary]. Research project of Flemish Environmental Agency, MIRA. MIRA/2006/03. Report INBO.R.2006.12. Research Institute for Nature and Forest, Brussels, pp. 156.

UBA (2004). Mapping manual 2004. Manual on methodologies and criteria for modelling and mapping critical loads and levels and air pollution effects, risks and trends. Umweltbundesamt. [online] URL: http://www.icpmapping.org

UNECE (2003). The condition of forests in Europe. Executive report 2003. United Nations Economic Commission for Europe, Geneva, pp. 42 .

van der Salm C, de Vries W (2000). Soil acidification in loess and clay soil in The Netherlands. Water, Air and Soil Pollution 120: 139-167. doi: 10.1023/A:1005254304043

van der Salm C, de Vries W (2001). A review of the calculation procedure for critical acid loads for terrestrial ecosystems. The Science of the Total Environment 271: 11-25. - doi: 10.1016/S0048-9697(00)00807-X

van Dobben HF, van Hinsberg A, Schouwenberg EPAG, Jansen M, Mol-Dijkstra JP, Wieggers HJJ, Kros J, de Vries W (2006). Simulation of critical loads for nitrogen for terrestrial plant communities in the Netherlands. Ecosystems 9: 32-45. - doi: 10.1007/s10021-005-0052-3 